\title{
ANALISIS PENGARUH VISUAL MERCHANDISING PADA PERILAKU IMPULSE BUYING: STUDI MEREK H\&M
}

\author{
${ }^{1}$ Andrea Rahardiana Putri, ${ }^{2}$ Adrian Achyar
}

\begin{abstract}
This article aims to investigate the impact of visual merchandising on impulse buying behavior; case study on fashion retail outlet: $H \& M$ Grand Indonesia, Central Jakarta. Our respondents in this study are H\&M consumers in this outlet who had experience in carrying out unplanned purchase transactions on products at H\&M Grand Indonesia outlets in the last two months. The numbers of our respondents are 120 people. We process our data using SPPS and Lisrel. The results show that the window display, in-store form, floor merchandising, and promotional signage have an effect on the behavior of impulse buying at the fashion retail outlets H\&M Grand Indonesia Jakarta Pusat.
\end{abstract}

Keyword: Window display; in-storeform; floor merchandising; promotional ignage; impulse buying

\begin{abstract}
ABSTRAK
Penelitian ini bertujuan untuk mengetahui Pengaruh Visual merchandising Pada Perilaku Impulse buying: Studi Kasus Pada Gerai Ritel Fashion H\&M Grand Indonesia Jakarta Pusat. Responden dalam penelitian ini adalah para konsumen H\&M Grand Indonesia Jakarta Pusat yang memiliki pengalaman melakukan transaksi pembelian tidak terencana terhadap produk di gerai H\&M Grand Indonesia dalam kurun waktu dua bulan terakhir sebanyak 120 responden. Desain penelitian ini adalah penelitian kuantitatif. Data penelitian ini diolah dengan perangkat lunak SPSS dan Lisrel. Hasil penelitian menunjukkan bahwa window display, in-store form, floor merchandising, dan promotional signage berpengaruh terhadap perilaku impulse buying di gerai ritel fashion H\&M Grand Indonesia Jakarta Pusat.
\end{abstract}

Keyword: Window display; in-storeform; floor merchandising; promotional ignage; impulse buying 


\section{Pendahuluan}

Perkembangan dunia ritel di masa sekarang ini semakin menggairahkan, berbagai pilihan ditawarkan ke pasar. Bisnis ritel di Indonesia masih menjanjikan tak hanya bagi produsen lokal maupun asing (Primus, 2017). Hal ini dapat dilihat dari bermunculannya berbagai ritel di kotakota besar, dimana masyarakat semakin dimanjakan dengan mudahnya mengakses pusat perbelanjaan belakangan tahun terakhir. Asosiasi Pengusaha Ritel Indonesia (APRINDO) meyakini pertumbuhan ritel pada tahun 2017 akan lebih baik. Pasalnya, APRINDO melihat kebijakan fiskal maupun moneter Indonesia jauh lebih tertata dan dapat diimbangi dibanding tahun sebelumnya (Wijayani, 2017). Sama dengan berkembangnya industri fashion di Indonesia yang semakin terlihat di pasar. Seperti diketahui, sub sektor fashion adalah penyumbang kontribusi terbesar kedua dari sektor ekonomi kreatif terhadap total Produk Domestik Bruto (PDB) Indonesia dalam setahun terakhir. Dengan nilai pasar mencapai Rp 180 triliun per tahunnya, industri fashion merupakan salah satu penyumbang terbesar pertumbuhan ekonomi Indonesia dari sektor ekonomi kreatif (Sudiarto, 2016). Kini, mulai dari merek buatan lokal hingga merek terkenal dari mancanegara tengah mantap melebarkan bisnisnya di dalam negeri, contohnya adalah Uniqlo yang gencar melebarkan bisnis sayapnya di Indonesia. Dalam kurun kurang dua tahun terakhir saja, label busana asal Jepang ini sudah membuka 6 gerai di Jakarta (Swanti, 2014). Begitu juga dengan ZARA, sudah cukup lama ekspansi di Indonesia, Zara kembali membuat gebrakan baru dengan membuka toko di Grand Indonesia Shopping Mall, Jakarta Pusat. Gerai brand high-street itu menjadi toko terluas di wilayah Asia Tenggara (Salvatrone, 2014). Hal tersebut membuat kompetisi dunia persaingan antar ritel fashion semakin meningkat. Begitu juga dengan ritel fashion asal Swedia, H\&M. Di Indonesia sendiri, setelah sukses membuka gerainya di Gandaria City dan Pondok Indah Mall, brand ritel asal Swedia H\&M membuka flagshipstore terbarunya di Grand Indonesia pada tahun 2014 (Chekka, 2014). H\&M yang membuka gerainya di Jakarta untuk meraup pasar produk fashion yang terus meningkat di kalangan anak muda (Aritonang, 2013).

H\&M merupakan salah satu fashion brand multinasional. H\&M (Hennes and Mauritz $\mathrm{AB})$ adalah perusahaan ritel pakaian Swedia, mereka terkenal sebagai brand untuk produk pakaian fast-fashion. Mereka menjual produknya untuk semua kalangan, pria, perempuan, remaja, dan anak-anak. 
Brand ini sudah mendunia, hadir di 43 negara. Jumlah pegawainya tahun 2011 mencapai sekitar 94.000 orang. Pada akhir tahun 2011, mereka memiliki 2.325 toko, dan pada Agustus 2012 mereka memiliki 2.629 toko. H\&M merupakan retailer global pakaian terbesar kedua. Mereka selalu mengontrol kualitas produk mereka, tim desain mereka mengontrol langkahlangkah produksi mulai dari planning, hingga produksi yang melibatkan 800 pabrik di Eropa dan Asia. Untuk Asia, mereka pertama kali membuka toko di Dubai, Uni Emirat Arab, tahun 2006. Tahun 2007 mereka mengembangkan sayap dengan membuka toko di Hongkong. Tahun 2008 mereka membuka toko pertama di Jepang. Kemudian mereka bergerak ke Korea Selatan, dan membuka toko Myeongdong, Seoul. Untuk Asia Tenggara, mereka membuka toko di Singapura tahun 2011, dan di Thailand serta Malaysia tahun 2012 ini. Untuk produk wanita mereka menjual produk seperti lingerie, jaket, mantel, kaos, blus, gaun, rok, pakaian atasan dan bawahan (Win, 2012).

Dengan fenomena semakin meningkatnya jumlah ritel fashion, maka dibutuhkan strategi menarik untuk mempertahankan pasarnya. Salah satunya dengan memanfaatkan strategi visual merchandising. Visual merchandising lebih dari sekedar window display yang menarik pelanggan. Hal ini lebih komprehensif, dimana tujuannya adalah mendapatkan konsumen kedalam toko dan membuat mereka membeli produk yang ada (Sheehan, 2017). Gerai ritel harus menjadi penjual paling produktif dan efisien, hal ini berhubungan dengan bagaimana peritel dapat mengoptimalkan gerainya untuk mendapatkan penjualan maksimum dengan menggunakan seni dan ilmu visual merchandising (Khan, 2016). Window display adalah salah satu senjata paling ampuh untuk menonjol dari kompetitor, begitu juga dengan mannequin display yang dapat menjadi taktik untuk memberi calon pelanggan referensi langsung dan segera setelah mereka dapat membayangkan produk pada diri mereka, peritel dapat menganggap bahwa hal tersebut berhasil (Khan, 2016). Secara psikologis, impulse buying dapat dikaitkan dengan beberapa sebab (Bianchi, 2016), yaitu:

1. Kebiasaan sejak kecil untuk mendapatkan kesenangan ketika memiliki barang baru

2. Fenomena FOMO (Fear Of Missing Out) yang nyata, ketika seorang individu merasa takut di masa mendatang bila tidak membeli suatu barang. 
Sedangkan secara biologis, impulse buying dapat diciptakan dengan beberapa strategi yaitu:

1. Menawarkan produk yang "pas" untuk konsumen

2. Menarik perhatian pengunjung dengan signage promosi

3. Membuat stimuli untuk melakukan pembelian strategic placement, seperti menaruh produk yang kurang laku didekat best-selling items.

Hal mengenai impulse buying berada dekat terhadap visual merchandising. Manajemen ritel harus memahami perilaku konsumen ini yang sering terjadi pada gerai ritel. Hal ini merupakan taktik pemasaran yang telah teruji dan benar, impulse buying adalah strategi ritel yang telah diandalkan selama beberapa dekade. Pedagang telah menempatkan barang murah secara strategis di sekitar jalur menuju kasir sejak tahun 1950-an. Hal ini sama seperti yang dilakukan oleh H\&M yang selalu meletakkan display kaus kaki di sekitar kasir. (Bianchi, 2016). Berdasarkan diskusi tersebut maka studi ini bertujuan untuk menganalisis pengaruh visual merchandising terhadap impulse buying pada H\&M Grand Indonesia.

\section{Tinjauan Pustaka}

\subsection{Visual merchandising}

Visual merchandising adalah alat yang digunakan perusahaan atau penjaga toko untuk menarik pembeli untuk melakukan pembelian yang tidak direncanakan (Bhatti \& Latif, 2013). Visual merchandising merupakan presentasi produk yang efektif yang mempengaruhi pembeli. Hal ini dapat tepat mengenai sasaran pada waktu yang tepat. Semua yang dilihat oleh konsumen, eksterior maupun interior, akan memberikan dampak positif. Peritel telah menyadari bahwa "hanya" sekedar menjual produk tidaklah penting, melainkan kepuasan dan kemudahan yang didapatkan oleh konsumen yang merupakan hal terpenting.

Stimuli dalam ritel termasuk pada ruang, produk, dan orang. Stimuli-stimuli tersebut kebanyakan "terlihat" melalui mata konsumen. Oleh karena itu, visual merchandising adalah hal yang tidak mahal untuk melakukan strategi pemasaran (Mehta \& Chugan, 2013). Visual merchandising meliputi eksterior dan interior. Eksterior pada toko meliputi salah satunya yaitu window display. Window display adalah media yang memberikan "kesan pertama" pada pikiran konsumen yang akan menentukan apakah mereka akan masuk ke dalam toko atau tidak. Selain itu, interior juga memiliki aspek 
penting dalam hal ini, karena interior yang terlihat bagus bagi konsumen akan mendorong ketertarikan konsumen untuk membeli. "Suasana" adalah strategi yang sangat penting. Visual merchandising berfokus pada bagaimana produk atau merek dikomunikasikan secara visual kepada konsumen.

Visual merchandising merupakan sebuah kegiatan yang bertujuan untuk mempromosikan barang yang dijual oleh perusahaan, terutama dilakukan oleh presentasi yang ada di dalam toko ritel. Suatu interior design dalam sebuah toko dapat membuat minat pelanggan untuk berada di dalam toko, kemudian mendorong pelanggan untuk dapat mengalah dari pertahanan psikologis pelanggan agar dengan mudah untuk membeli (Davies and Ward, 2002). Dunne dan Lusch (2006) juga mengatakan bahwa display yang ada di dalam toko dapat memunculkan kesan baik serta artistik untuk para pelanggan, hal ini kemudian akan menciptakan suatu persentasi dari visual merchandising untuk para pelanggan.

Terdapat tujuan utama dari visual merchandising, yaitu untuk menciptakan suatu lingkungan yang masuk akal dan menyenangkan dari sisi visual yang nantinya akan memenangkan perhatian para pelanggan agar terjadi peningkatan dalam penjualan. Para peritel harus dapat membuat lingkungan tokonya menjadi unik untuk meningkatkan pengalaman berbelanja berbeda bagi pelanggan. Faktor simulasi visual serta komunikasi sudah lama menjadi aspek yang penting dari sebuah toko ritel (McGoldrick, 2002).

Dalam proses mengelola visual merchandising, faktor-faktor kreatif sangatlah dibutuhkan. Para peritel besar pada umumnya mempunyai divisi sendiri yang menangani urusan visual merchandising. Banyak hal yang dapat dilakukan oleh peritel saat mengembangkan kreatifitas yang dimilikinya (Amir, 2003). Visual merchandising kerap bersentuhan dengan teknik-teknik tertentu dalam penyajian produk di dalam toko ritel untuk dapat membuat situasi dan suasana yang diinginkan (Ma'aruf, 2016). Terdapat tujuh prinsip untuk desain utama dalam aktivitas display, yaitu adalah harmoni, irama, warna, proporsi, penekanan, keseimbangan, dan pencahayaan (BastowShoop, 1991).

\subsection{Impulse buying}

Impulse buying telah lama menjadi enigma di dunia pemasaran. Dikarenakan impulse buying adalah suatu perilaku konsumen yang disebut-sebut berasal dari titik gelap 
dunia pemasaran, termasuk berbagai penelitian yang mengatakan bahwa impulse buying didorong oleh faktor hedonisme. Ketika fenomena impulse buying dilihat dari sisi psikologis, hal ini cenderung berada pada tahap emosional yang tinggi dan keputusan yang tidak dipikirkan dengan matang. Hal tersebut disebabkan oleh stimuli-stimuli tertentu yang membuat seorang individu berada di bawah kontrol (Kalla \& Arora, 2011).

Perilaku impulse buying adalah melakukan pembelian yang tercipta tanpa berfikir terlebih dahulu. Hal tersebut terjadi tanpa evaluasi dari beberapa hal seperti kebutuhan dan harga. Kata kunci untuk perilaku ini adalah spontan, intens, dan keinginan yang menyenangkan dan yang teramat besar untuk membeli (Mehta \& Chugan, 2013). Impulse buying adalah tindakan pembelian yang tidak mendapat pengakuan secara sadar dari hasil sebuah niat membeli maupun petimbangan tertentu yang telah muncul sebelum masuk ke sebuah toko. Tindakan ini dilakukan oleh konsumen karena adanya perasaan dan respon positif yang kuat untuk suatu produk. (Mowen dan Minor, 2002). Impulse buying merupakan cara untuk mendorong calon konsumen untuk melakukan sebuah tindakan yang muncul karena adanya daya tarik akan suatu sentiment (Manning dan Reece, 2006).
Dari definisi yang ada, impulse buying adalah suatu hal yang alamiah dengan reaksi yang cepat. Hal ini terjadi ketika pelanggan masuk ke sebuah toko dan membeli produk di toko tersebut tanpa ada rencana yang dibuat sebelumnya.

Hal mengenai impulse buying telah menjadi perhatian bagi para praktisi dan peneliti sejak lama. POPAI (Point of Purchase Advertising Institute) mengatakan bahwa terdapat sekitar $75 \%$ pembelian yang terjadi di supermarket dilakukan dengan tidak terencana sebelumnya. Para ahli pun mengatakan bahwa perilaku impulse buying ini telah berkembang dengan signifikan didalam masyarakat. Pelanggan seringkali membeli dengan didasari suasana hati, hasrat dan emosi yang dirasakan saat itu (Verplanken dan Herabadi, 2001).

Impulse buying adalah pembelian yang tidak rasional dan masuk ke dalam golongan pembelian cepat dan tak terencana. Adanya konflik antara emosional dan konflik pikiran mempengaruhi perilaku ini. Dorongan emosional terkait dengan perasaan yang intens yang dimunculkan dengan membeli suatu produk, didukung juga dengan adanya keinginan untuk membeli barang dengan cepat dan segera, sehingga konsekuensi dan risiko negatif 
dikesampingkan demi merasakan kepuasan, walaupun hal ini menciptakan konflik di dalam pikiran (Verplanken dan Herabadi, 2001).

\subsection{Visual merchandising dan Impulse buying}

Window display adalah medium yang menciptakan 'first impression' terhadap pikiran konsumen untuk masuk ke dalam toko (Darden dan Darden, 1983). Window display adalah touch point utama dari sebuah toko ke konsumen. Marketer seharusnya dapat meningkatkan penjualan toko mereka dengan berinovasi dalam hal display. Window display akan meningkatkan walk-ins ke dalam toko. Dalam penelitian sebelumnya telah ditemukan bahwa terdapat hubungan secara langsung atau directional relationship dimana window display secara signifikan mempengaruhi impulse buying behaviour dari konsumen (Mehta dan Chugan, 2013). Pembelian tidak terencana pada toko ritel dapat ditingkatkan dengan adanya display (Cox, 1970).

\section{Hipotesis Pertama}

Window display berpengaruh terhadap perilaku impulse buying di gerai ritel fashion H\&M Grand Indonesia Jakarta Pusat.

Isyarat-isyarat yang diberikan oleh in-store menarik bagi konsumen, hal ini akan menurunkan pertahanan psikologis dan membantu untuk melakukan pembelian (Walters dan White, 1987). Dalam penelitian sebelumnya telah ditemukan bahwa terdapat hubungan antara impulse buying dan in-store form (Mehta dan Chugan, 2013). Ketika konsumen terekspos dengan stimuli visual ini, mereka akan cenderung melakukan keputusan pembelian secara tidak terencana (Mehta dan Chugan, 2013).

\section{Hipotesis Kedua}

In-store form berpengaruh terhadap perilaku impulse buying di gerai ritel fashion H\&M Grand Indonesia Jakarta Pusat.

Dalam penelitian sebelumnya telah ditemukan bahwa terdapat hubungan yang signifikan antara impulse buying dan floor merchandising (Mehta dan Chugan, 2013). Hal-hal di dalam dimensi floor merchandising seperti rak, gondola dan walking space akan memberikan kemudahan berbelanja bagi para konsumen. Maka floor merchandising seharusnya akan sangat efektif untuk meningkatkan perilaku impulse buying (Mehta dan Chugan, 2013).

\section{Hipotesis Ketiga}

Floor merchandising berpengaruh terhadap perilaku impulse buying di gerai 
ritel fashion H\&M Grand Indonesia Jakarta Pusat.

Dalam penelitian sebelumnya telah ditemukan bahwa terdapat hubungan yang signifikan antara impulse buying dan promotional signage (Mehta dan Chugan, 2013). Promotional signage akan memberikan pengalaman yang lebih di toko. Promotional signage akan menggantikan tugas seorang sales person untuk membantu konsumen. Hal ini akan mempermudah konsumen ketika berbelanja. Jika promotional signage diberikan dengan cara yang kreatif, maka hal ini akan berguna untuk meningkatkan perilaku impulse buying (Mehta dan Chugan, 2013).

\section{Hipotesis keempat}

Promotional signage berpengaruh terhadap perilaku impulse buying di gerai ritel fashion H\&M Grand Indonesia Jakarta Pusat.

\section{Metode Penelitian}

Pada tahap awal sebelum dilakukan pengumpulan dan pengolahan data adalah peneliti melakukan wording test terhadap 11 (sebelas) orang. Sebagai hasil dari wording test, terdapat beberapa perubahan diantara kalimat-kalimat yang ada di dalam kuesioner penelitian. Selanjutnya dilakukan pretest dilaksanakan dengan menggunakan hasil dari pengisian kuesioner 30 (tiga puluh) orang responden. Setelah pretest, validitas dan reliabilitas alat ukur diuji. Hasil dari uji validitas pretest pada tabel-tabel diatas menghasilkan nilai component matrix > 0.5, hal ini menunjukan bahwa nilai variabel laten valid dan masing-masing variabel teramati merepresentasikan variabel laten.

Uji reliabilitas dilakukan untuk mengukur konsistensi penelitian. Suatu hasil uji reliabilitas dikatakan reliabel jika cronbach Alpha yang dihasilkan > 0,6 (Malhotra, 2007). Kemudian main-test dilakukan pada 120 orang responden. Analisis Structural Equation Modelling (SEM) kemudian dilakukan pada keseluruhan sampel yang ada.

\section{Hasil dan Diskusi}

Dalam penelitian ini terdapat empat hipotesis yang diangkat. Analisis pengujiannya dilakukan dengan tingkat signifikansi sebesar 5\%, yang menghasilkan critical t-value sebesar \pm 1,96. Apabila t-value yang besar nilai absolutnya yang didapat $\geq 1,96$ maka hipotesis dapat diterima, kemudian apabila t-value yang besar nilai absolutnya yang didapat $<1,96$ maka hipotesis tidak didukung. Hasil olah SEM dapat dilihat pada gambar 1 di bawah ini. 
Gambar 1. Model Struktural

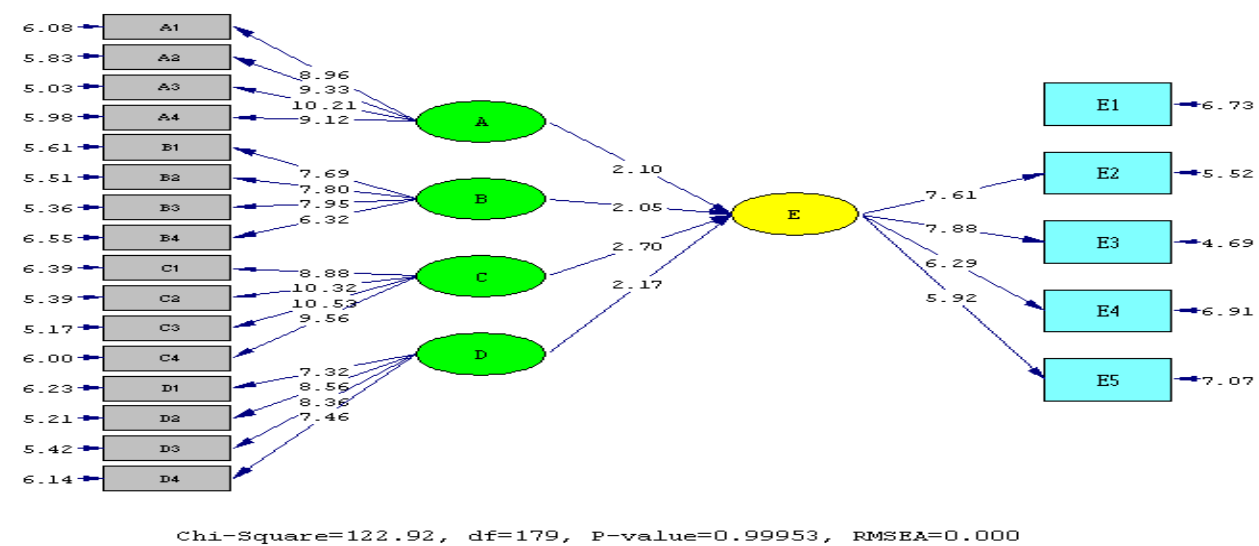

Berdasarkan gambar 1 diatas, menurut penilaian yang terdapat pada nilai tvalue yang ada pada hipotesis 1 adalah lebih besar dari 1,96 yaitu sebesar 2,10. Maka nilai tersebut menandakan window display berpengaruh secara positif terhadap perilaku impulse buying di gerai ritel fashion $\mathrm{H} \& \mathrm{M}$ Grand Indonesia Jakarta Pusat secara signifikan. Disimpulkan bahwa hipotesis 1 dapat diterima dan window display dapat meningkatkan perilaku impulse buying. Jika dibandingan dengan penelitian sebelumnya (Mehta dan Chugan, 2013), hipotesis ini memiliki hasil yang sama. Terdapat hubungan positif yang signifikan antara window display dengan perilaku impulse buying.

Berdasarkan penilaian yang terdapat pada Gambar 1, nilai t-value yang ada pada hipotesis 2 adalah lebih besar dari 1,96 yaitu sebesar 2,05. Maka nilai tersebut menandakan in-store form berpengaruh secara positif terhadap perilaku impulse buying di gerai ritel fashion H\&M Grand Indonesia Jakarta Pusat secara signifikan. Disimpulkan bahwa hipotesis 2 dapat diterima dan Instore form dapat meningkatkan perilaku impulse buying. Jika dibandingan dengan penelitian sebelumnya (Mehta dan Chugan, 2013), hipotesis ini memiliki hasil yang tidak sama. Tidak terdapat hubungan antara in-store form dengan perilaku impulse buying.

Berdasarkan penilaian yang terdapat pada Gambar 1, nilai t-value yang ada pada hipotesis 3 adalah lebih besar dari 1,96 yaitu sebesar 2,70. Maka nilai tersebut menandakan floor merchandising berpengaruh secara positif terhadap perilaku impulse buying di gerai ritel fashion $\mathrm{H} \& \mathrm{M}$ Grand Indonesia Jakarta 
Pusat secara signifikan. Disimpulkan

floor merchandising dapat meningkatkan perilaku impulse buying. Jika dibandingkan dengan penelitian sebelumnya (Mehta dan Chugan, 2013), hipotesis ini memiliki hasil yang sama. Terdapat hubungan positif yang signifikan antara floor merchandising dengan perilaku impulse buying.

Adapun hipotesis terakhir, berdasarkan penilaian yang terdapat pada Gambar 1 , nilai t-value yang ada pada hipotesis 4 adalah lebih besar dari 1,96 yaitu sebesar 3,85. Maka nilai tersebut bahwa hipotesis 3 dapat diterima dan menandakan promotional signage berpengaruh secara positif terhadap perilaku impulse buying di gerai ritel fashion H\&M Grand Indonesia Jakarta Pusat secara signifikan.

Disimpulkan bahwa hipotesis 4 dapat diterima dan promotional signage dapat meningkatkan perilaku impulse buying. Jika dibandingan dengan penelitian sebelumnya (Mehta dan Chugan, 2013), hipotesis ini memiliki hasil yang sama. Terdapat hubungan positif yang signifikan antara promotional signage dengan perilaku impulse buying.

Tabel 1. Simpulan Hipotesis 1-4

\begin{tabular}{|c|c|c|c|c|}
\hline Hipotesis & Pernyataan & $\begin{array}{c}\mathrm{t}-\mathrm{value} \\
\text { (absolute) }\end{array}$ & t tabel & Keterangan \\
\hline $\mathrm{H}_{1}$ & $\begin{array}{l}\text { Window display berpengaruh terhadap } \\
\text { perilaku impulse buying di gerai ritel } \\
\text { fashion H\&M Grand Indonesia Jakarta } \\
\text { Pusat }\end{array}$ & 2,10 & & signifikan \\
\hline $\mathrm{H}_{2}$ & $\begin{array}{l}\text { In-store form/ mannequin display } \\
\text { berpengaruh terhadap perilaku impulse } \\
\text { buying di gerai ritel fashion H\&M Grand } \\
\text { Indonesia Jakarta Pusat }\end{array}$ & 2,05 & & signifikan \\
\hline $\mathrm{H}_{3}$ & $\begin{array}{l}\text { Floor merchandising berpengaruh } \\
\text { terhadap perilaku impulse buying di } \\
\text { gerai ritel fashion } \mathrm{H} \& \mathrm{M} \text { Grand } \\
\text { Indonesia Jakarta Pusat }\end{array}$ & 2,70 & 1,70 & signifikan \\
\hline $\mathrm{H}_{4}$ & $\begin{array}{l}\text { Promotional signage berpengaruh } \\
\text { terhadap perilaku impulse buying di } \\
\text { gerai ritel fashion H\&M Grand } \\
\text { Indonesia Jakarta Pusat }\end{array}$ & 3,85 & & signifikan \\
\hline
\end{tabular}




\section{Kesimpulan}

Berdasarkan hasil pengolahan data dan analisis data yang telah dijelaskan pada bab sebelumnya, maka peneliti memperoleh beberapa kesimpulan, diantaranya adalah sebagai berikut:

1) Window display berpengaruh terhadap perilku impulse buying di gerai ritel fashion H\&M Grand Indonesia Jakarta Pusat. Hal ini berarti, semakin tinggi windows display yang dimiliki oleh gerai ritel fashion, maka semakin tinggi perilaku impulse buying di gerai tersebut.

2) In-store form berpengaruh terhadap perilaku impulse buying di gerai ritel fashion H\&M Grand Indonesia Jakarta Pusat. Hal ini berarti, semakin tinggi in-store form yang dimiliki oleh gerai ritel fashion, maka semakin tinggi perilaku impulse buying di gerai tersebut.

3) Floor merchandising berpengaruh terhadap perilaku impulse buying di gerai ritel fashion $\mathrm{H} \& \mathrm{M}$ Grand Indonesia Jakarta Pusat. Hal ini berarti, semakin tinggi floor merchandising yang dimiliki oleh gerai ritel fashion, maka semakin tinggi perilaku impulse buying di gerai tersebut.

4) Promotional signage berpengaruh terhadap perilaku impulse buying di gerai ritel fashion $\mathrm{H} \& \mathrm{M}$ Grand
Indonesia Jakarta Pusat. Hal ini berarti, semakin tinggi promotional signage yang dimiliki oleh gerai ritel fashion, maka semakin tinggi perilaku impulse buying di gerai tersebut.

Berdasarkan pada hasil penelitian ini, dapat ditemukan hasil bahwa visual merchandising berpengaruh secara positif terhadap perilaku impulse buying di gerai ritel fashion $\mathrm{H} \& \mathrm{M}$ Grand Indonesia Jakarta Pusat. Oleh karena itu, ada beberapa hal yang perlu diperhatikan oleh pihak manajer atau perusahaanya itu meningkatkan visual merchandising yang terdiri dari window display, in-store form, floor merchandising, dan promotional signage secara umum baik secara bersamasama maupun sendiri-sendiri dengan melihat kemampuan dari kondisi perusahaan.

\section{Daftar Pustaka}

Amir, M.T. (2003). Dinamika Pemasaran: Jelajahi dan Rasakan. Jakarta: Raja Grafindo Persada.

Aritonang, M. (2013). H\&M comes to town for fashion and more. Diakses dari: http://www.thejakartapost.com/news/2 013/10/12/hm-comes-town-fashionand-more.html. 
Assauri, S. (2013). Manajemen Pemasaran. Jakarta: Rajawali.

Bastow-Shoop dan Holly. (1991). Visual Merchandising A Guide for Small Retailers. Curtiss Hall: Lowa State University.

Bell, J., dan Ternus, K. (2012). Silent Selling $4^{\text {th }}$ Ed. New York: Fairchild.

Berman, B., dan Joel R.E. (2001). Retail Management A Strategic Approach. New Jersey: Prentice Hall.

Bhatti, K, L., dan Latif, S. (2013). The Impact of Visual merchandising on Consumer Impulse buying Behaviour. Proceedings of $4^{\text {th }}$ Asia-Pacific Business Research Conference 30 September - 1 October 2013, Bayview Hotel, Singapore.

Bianchi, J. (2016). Impulse buying: How Retailers Can Get Customers to Buy More on the Fly. Diakses dari: https://www.shopify.co.id/retail/impuls e-buying-how-retailers-can-getcustomers-to-buy-more-on-the-fly.

Bungin, H.M. (2005). Metodologi Penelitian Kuantitatif. Jakarta: Kencana Prenamedia.

Chekka. (2014). H\&M Hadir di Grand Indonesia. Diakses dari: http://www.harpersbazaar.co.id/articles
/read/3/2014/812/HM-Hadir-di-GrandIndonesia.

Cox, K. (1970). The Effect of Shelf Space upon Sales of Branded Products. Journal of Marketing Research, 7(Februari), pp.55-58.

Davies, B., dan Ward, P. (2002). Managing Retail Consumption. London: Wiley.

Darden, W.R., Erdem, O. dan Darden, D.K. (1983). A comparison and test of three casual models of patronage intentions, Patronage Behavior and Retail Management. New York: North Holland.

Dennis C.E., Fenech, T., dan Merrilees, W. (2005). The Business of E-retailing. London: Routledge.

Diamond, E., dan Diamond, J. (2007). The Visual merchandising Concept in a Contemporary Environment. $4^{\text {th }}$ Ed. Prentice Hall.

Dunne, P.M., dan Lusch, F.R. (2006). Retailing. South Western: Thomson.

Engel, J.F, Blackwell dan Miniard. (1995). Perilaku Konsumen. Jakarta: Binaputra.

Gilbert, David. (2003). Retail marketing management, $2^{\text {nd }}$ Ed. England: Prentice Hall. 
Gopal, V. (2006). Visual merchandising: An Introduction. ICFAI University Press.

Hair, J., et al. (2010). Multivariate Data Analysis. New York: Pearson.

Hartono, J. (2013). Metodologi Penelitian Bisnis Salah Kaprah dan Pengalamanpengalaman. Edisi kelima. Yogyakarta: BPFE.

Indriantoro, N., dan Supomo. (2002). Metodologi Penelitian Bisnis Untuk Akuntansi dan Manajemen, Edisi Pertama, Yogyakarta: BPFE.

Jain, V., Sharma, A., dan Narwal, P. (2012). Impact of visual merchandising on consumer behavior towards women's apparel. International Journal of Research in Management.

Kalla, M.S., dan Arora, P.A. (2011). Impulse buying: A Literature Review. Global Business Review, 12(1), pp.145-157.

Khan, H. (2016). A Fool-Proof Guide to Creating Window displays that Turn Heads and Drive Foot Traffic. Diakses dari:

https://www.shopify.com/retail/120058 947-a-fool-proof-guide-to-creatingwindow-displays-that-turn-heads-anddrive-foot-traffic.
Khan, H. (2016). Visual merchandising 101: How to Create Store Designs With High-Converting Displays. Diakses dari: https://www.shopify.com/retail/120040 003-visual-merchandising-101-how-tocreate-store-designs-with-highconverting-displays.

Khan, H. (2016). How To Create Retail Store Interiors That Get People To Purchase Your Products. Diakses dari: https://www.shopify.co.id/retail/12005 7795-how-to-create-retail-storeinteriors-that-get-people-to-purchaseyour-products.

Kotler, P. (2007). Manajemen Pemasaran. Jakarta: Indeks.

Kotler, Philip dan Gary Armstrong. (2008). Prinsip-prinsip Pemasaran. Edisi. 12. Jilid 1. Jakarta: Erlangga.

Levy M. dan Weitz B.A. (2007). Retailing Manajement. $6^{\text {th }}$ Ed. Boston: Mc Graw Hill.

Lupiyoadi, R., dan Ikhsan R.B.. (2015). Praktikum Metode Riset Bisnis. Jakarta: Salemba Empat.

Malhotra, N.K. (2009). Riset Pemasaran. Edisi keempat Jilid 1. Jakarta: PT Indeks. 
Ma'ruf, Hendri. (2005). Pemasaran Ritel. Jakarta: Gramedia.

Manning, G.L. dan Barry L.R. (2006). Selling Today. Edisi kedelapan. Jakarta: Indeks.

Mardalis. (2008). Metode Penelitian Suatu Pendekatan Proposal. Jakarta: Bumi Aksara.

Mattila, A.S., dan Wirtz, J. (2008). The role of store environmental stimulation and social factors on impulse purchasing. Journal of Services Marketing.

McGoldrick, P. (2002). Retail Marketing. New York: McGraw-Hill.

Mehta, N.P. dan Chugan, P K. (2013). The Impact of Visual merchandising on Impulse buying Behavior of Consumers: A Case from Central Mall of Ahmedabad India. Universal Journal of Management.

Mowen, C.J., dan Minor, M. (2002). Perilaku Konsumen. Jakarta: Erlangga.

Mukhtar. (2013). Metode Praktis Penelitian Deskriptif Kualitatif. Jakarta: Referensi.

Prasad, K.A., dan Vetrivel, S.C. (2016). An Empirical Study on Visual merchandising and Its Impact on
Journal of Business and Management (IOSR-JBM) 18(11), pp.08-14.

Primus, J. (2017). Bisnis Ritel di Indonesia Masih Menjanjikan. Diakses dari: http://bisniskeuangan.kompas.com/read /2017/05/08/204517926/bisnis.ritel.di.i ndonesia.masih.menjanjikan.

Risch, E.H. (1991). Retail merchandising. USA: MacMillan.

Salvatrone, J. (2014). Zara Buka Toko Terbesar Se-Asia Tenggara di Grand Indonesia. Diakses dari: https://wolipop.detik.com/read/2014/12 /01/182346/2764493/233/zara-bukatoko-terbesar-se-asia-tenggara-digrand-indonesia.

Sekaran, U. (2003). Research Methods for Business: a Skill-Building Approach. New York: John Wiley \& Sons.

Sheehan, A. (2017). 10 Unique Visual merchandising Ideas You Should Steal. Diakses dari: https://www.shopify.co.id/retail/10unique-visual-merchandising-ideasyou-should-steal.

Sigit, S. (2001). Pengantar Metodologi Penelitian. Yogyakarta: Pena Persada Offset.

Sudiarto, R. (2016). Norlive Siap Go International di Bidang Fashion. 
Diakses

dari:

https://swa.co.id/youngster-

inc/entrepreneur-youngsterinc/norlive-

siap-go-international-di-bidang-

fashion.

Sugiyono. (2001). Metode Penelitian

Bisnis. Bandung: Aklfa-Beta.

Swanti, E. (2014). Uniqlo Buka Gerai Ke-

6 di Grand Indonesia. Diakses dari:

http://lifestyle.liputan6.com/read/21238

51/uniqlo-buka-gerai-ke-6-di-grand-

indonesia.

Tullman M.L. dan Clark, R.K. (2004).

Revitalizing Visual merchandising-

Restoring Balance to Retail

Environment Entails Engaging all Five

Senses.

Umar, H. (2013). Metode Penelitian untuk

Skripsi dan Tesis Bisnis. Jakarta:

Rajawali.

Underhill, P. (2009). Why We Buy: The Science of Shopping, Simon and Schuster, New York.

Utami., Widya C. (2006). Manajemen Ritel. Jakarta: Salemba.

Verplanken, B., dan Herabadi. (2001). Individual Differences in Impulse buying Tendency: Feeling and No Thinking. European Journal of Personality. 15, pp.71-83.
Walters, D., dan White, D. (1987). Retail Marketing Management, Basingstock: Macmillan.

Wijayani, S. (2016). APRINDO Optimistis Pertumbuhan Ritel Akan Lebih Baik Tahun 2017. Diakses dari: http://marketeers.com/aprindooptimistis-pertumbuhan-ritel-akanlebih-baik-tahun-2017.

Wijanto, S.H. (2008). Structural Equation Modeling. Yogyakarta: Graha Ilmu.

Win. (2012). H\&M, Retailer Pakaian Terbesar Kedua. Diakses dari: https://www.vemale.com/brand/15761h-m-retailer-pakaian-terbesarkedua.html. 